subsidence. For the proper estimation of the efficiency of the cause invoked, it is requisite that this should be clearly set forth. That lateral displacement by weight of accumulated sediment together with actual compression of the rocks below may take place in certain cases is extremely probable.

The assumption of the existence of a zone of molten rock at a certain distance below the surface of the earth in so sensitive a condition as to respond to the weight of accumulation by becoming solid or that of denudation by becoming liquid is rather a large one, especially when the physical part is unsupported by experiment or quantitative determination. If these were supplied, it would be a fit subject for investigation, but the suggestion fails as a general explanation of subsidence and elevation, even if the assumptions are admitted, inasmuch as it does not account for the elevation of areas of former great sedimentation, which is one of the most striking facts of geology.

T. Mellard Reade.

THE NOMENCLATURE OF. AMMONITES.

SIR,-I had not much hope of converting Mr. Buckman from what, in common with Mr. Haddow, I conceive to be the error of his ways; but I wished to protest against the system of which he is an exponent.

$\mathrm{He}$ still assumes that Agoceras and Arietites are genera, which is exactly what I ventured to question. He says I do not attempt to discuss Lioceras, but I should have thought he would understand that it could be treated in the same way as Harpoceras (if it is a group of equal value). Let us write in catalognes Ammonites (Lioceras) elegans; specialists will doubtless prefer to call it Linceras elegans; but most geologists will probably be content with Ammonites elegans, regarding Lioceras merely as a subgeneric name.

My chief point, which Mr. Buckman entirely fails to notice, is this, that if the specialists rank Harpoceras, Lioceras, etc., as genera, each of them may be accredited with a species having the same specific name. Fancy half a dozen different $A m m$. elegans referable to an equal number of these so-called genera.

A. J. Jukes-Browne.

\title{
"GEOLOGY FOR ALL."
}

Srr,-While thanking you for your notice of "Geology for All," perhaps you will permit me to say that what is called a " slip" is explained by the context, and is in accord with the spirit and intention of the book, while the high per-centage of silica in orthoclase is duly acknowledged on page 58, where the fact is wanted.

I may add that my aim was to find a new and intermediate path between the two old and well-beaten ones of Academic or Text-book geology and so-called "popular" or entertaining geology, neither of which in my humble opinion is likely to lead to the end I have in view, namely, a general knowledge of geology by all well-educated people. In the days of Buckland and Hugh Miller, fossils were 